\title{
BIODEGRADATION POTENTIAL OF RHIZOSPHERIC MICROORGANISMS OF RHIZOPHORA RACEMOSA IN CRUDE OIL CONTAMINATED MANGROVE SWAMP IN THE NIGER DELTA
}

\author{
${ }^{* 1,3}$ Aina, O. R., ${ }^{1}$ Atuanya, E. I., ${ }^{1}$ Oshoma, C. E., ${ }^{2}$ Omotayo, A. E. \& ${ }^{3}$ Olaleye, O. N.
}

\author{
${ }^{*}$ Department of Microbiology, Faculty of Life Sciences, University of Benin, Benin City, Nigeria \\ ${ }^{2}$ Department of Microbiology Department, Faculty of Science University of Lagos, Akoka Nigeria \\ ${ }^{3}$ Department of Biological Sciences, School of Pure and Applied Sciences, Lagos State Polytechnic, Ikorodu, Nigeria.
}

*Corresponding Author's E-mail: duni15nov@ gmail.com Phone: +2348037535828

\begin{abstract}
$\mathrm{R}$ hizophora racemosa (red mangrove tree) belongs to the family Rhizophoraceae; it is an important constituent of the mangrove swamp in Niger Delta, an oil producing region in Nigeria. The remediation of soils containing organic pollutants is possible with the use of microbial communities when the ecology is understood for potentials maximization. This study investigated the biodegradation potential of rhizospheric microorganisms of Rhizophora racemosa in crude oil- contaminated mangrove swamp in the Niger Delta.The total microbial count was determined by the serial dilution method. The hydrocarbon-utilizing bacteria and fungi were enumerated using Mineral Salts Agar containing crude oil as the sole carbon source. The biodegradation potential of these rhizomicrobes was determined using screen test, shake flask degradation tests, Total Organic Gas (TOG) and Total Petroleum Hydrocarbon (TPH) InfraCal Analyzer (HATR-T2 and CH). The turbidity, total organic gas (TOG-N) and total petroleum hydrocarbon were measured weekly for twenty-eight days. Hydrocarbon-degrading microbes isolated from the rhizosphere were identified as Marinococcus sp., Azotobacter sp., Acinetobacter sp. Aspergillus niger, Aspergillus flavus and Candida albicans. The highest rate of TPH reduction was recorded in Acinetobacter sp. (from $150 \mathrm{mg} / \mathrm{L}$ on day 1 to $<0.0031 \mathrm{mg} / \mathrm{L}$ on day 14). This was followed by Candida albicans $(148 \mathrm{mg} / \mathrm{L}$ on day 1 to $2.68 \mathrm{mg} / \mathrm{L}$ on day 28$)$ and Aspergillus flavus $(150 \mathrm{mg} / \mathrm{L}$ on day 1 to $4.21 \mathrm{mg} / \mathrm{L}$ on day 28) In conclusion, it can be inferred that the some rhizospheric microbes of Rhizophora racemosa can efficienctly degrade hydrocarbon up to $100 \%$ rate over a period of 28 days.
\end{abstract}

Keywords: Rhizophora racemosa, Rhizospheric, Rhizomicrobes, Mangrove swamp, TPH and TOG analyzer, Shake flask degradation test, Biodegradation potential

LICENSE: This article by African Journal of Health, Safety and Environment (AJHSE) is licensed and published under the Creative Commons Attribution License 4.0 International License, which permits unrestricted use, distribution, and reproduction in any medium, provided this article is duly cited.

COPYRIGHT: The Author(s) completely retain the copyright of this published article.

OPEN ACCESS: The Author(s) approves that this article remains permanently online in the open access (OA) model

QA: This Article is published in line with "COPE (Committee on Publication Ethics) and PIE (Publication Integrity \& Ethics)". 


\section{INTRODUCTION}

Rhizophora racemosa is a special plant which can survive in marine environment. It is common along the coastal regions where there is constant flooding. It belongs to the family Rhizophoraceae and it is the most common of this family in West Africa. Other species in this family include Rhizophora mangle and Rhizophora harrisoni. $R$. racemosa has a forklike root which has breathing pores called pneumatophores (Adegbehin, 1993; Giri et al., 2010). Mangrove swamp is an ecosystem which can be aquatic in nature during the raining seasons and a little bit dry in dry seasons. It is a waterlogged ecosystem and can also be salty. The ecosystem is made up of some plants that have the ability to survive and live conveniently in water; some of these plants are ferns, palms, trees, shrubs and vines (Adegbehin, 1993; Flowers and Colmer, 2015). This ecosystem is a major source of food and materials for people in the coastal region to which the Niger Delta belongs. Mangrove forests provide fruits, firewood, timber, charcoal, fish etc. for people living in the region. (Adegbehin, 1993; Eleanya et al., 2015).

Environmental pollution is one of the woes brought upon humanity as a result of infrastructural and industrial development. In the past century our environments have been facing a lot of challenges as a result of constant contamination with persistent substances, some are organic, inorganic and xenobiotic in nature (Atlas and Hazen, 2011). The use of advanced technologies for production especially in the oil sector has a lot of adverse environmental health effects. Also the disposal of wastes generated from crude-oil production is a worldwide problem in that hydrocarbon wastes pollute and destabilize the air, aquatic, terrestrial and mangrove ecosystems (John et al., 2010).

Different methods have been employed to eradicate or minimize these environmental challenges. Methods like excavation, incineration and land filling have been used in past times; these methods were found to be costly, vigorous and time consuming (John et al., 2010). This led to the search for better, less expensive, easy and time saving technologies. The breakdown of toxic substances such as hydrocarbons can be done naturally by microbial degradation (Amanchukwu et al., 1989). In most cases, microbial degradation is a detoxifying mechanism and in the cases of some composite compounds, it is the only mechanism, which leads to comprehensive mineralisation (Nnubia and Okpokwasili, 1992).

It was discovered that the association between the plant and the microorganisms found in the root region called rhizosphere can be effectively used to clean up polluted ecosystems (Kuiper et al., 2004). This process is referred to as rhizoremediation and it is a widely accepted technology. Researches are still ongoing in order to improve on these methods or better still to discover new methods. Rhizosphere is a unique region between the root of a plant and its immediate soil environment. The rhizosphere is rich in organic substances produced from the root of the plant; these organic substances include exudates, mucilage and cellulose which are by products of processes like photosynthesis and shedding off old cells (Brime-Combe et al., 2007). A lot of microbial activities take place in this region. The activities of these microbes bring about plant growth and root development. Microbes found in the rhizosphere can also help the plant to withstand the toxicity of contaminants including crude oil hydrocarbons and heavy metals. Most mangrove plants appear to tolerate toxicity of crude oil better than other plants (Atuanya et al., 2013). Since $R$. racemosa is commonly found in mangrove swamps and no study has demonstrated the biodegradation potential of its rhizospheric microorganisms in crude oil contaminated mangrove swamps in the Niger Delta, hence this study. The objectives of the study were to isolate and identify bacteria and fungi found in the 
rhizosphere of $R$. Racemosa and to determine their degradation potentials in a crude-oil contaminated mangrove swamp.

\section{SIGNIFICANCE OF THE STUDY}

Environmental pollution by petroleum products remain an unavoidable consequence of oil exploitation, transportation and distribution activities. In finding solutions to the problem of environmental pollution posed by activities of oil exploration such as oil pipe cleaning, oil spillages and inappropriate disposal of hydrocarbon contaminated wastes, hydrocarbon- degrading microorganisms can be identified and harnessed to formulate products that will boost the biodegradation of petroleum hydrocarbon in hydrocarbon contaminated environments. This in turn will benefit the United Nations, in that it will contribute to the achievement of the Sustainable Development Goal (SDG) 15.This SDG 15 is to protect, restore and promote sustainable use of terrestrial ecosystems, sustainably manage forests, combat desertification, halt and reverse land degradation and halt biodiversity loss.

\section{METHODOLOGY}

\section{DESCRIPTION OF SAMPLING SITE}

The mangrove swamp soil sample (sandy loam) used for this research work was collected from Ekpan community near (Edjeba-Warri) of Uvwie Local Government area of Delta state, Nigeria. Uvwie is located in the area roughly between longitudes 5.40' and 5.50' east of latitudes 5.30 and 5.50 north. (Wikipedia).

\section{COLLECTION OF RHIZOSPHERIC SOIL FOR MICROBIAL ANALYSIS}

A seedling of Rhizophora racemosa was uprooted and the soil surrounding the root of the mangrove seedling was collected together with some of the adhering roots. Five gram of the soil was weighed and air dried at normal room temperature

\section{ENUMERATION OF HYDROCARBON UTILIZING BACTERIA AND FUNGI}

A serial dilution up to $10^{-3}$ and triplicates of each dilution was prepared. Fungal plates were incubated aerobically at $25^{\circ} \mathrm{C}$ for 72 hours and bacterial plates were incubated at $30^{\circ} \mathrm{C}$ for 48 hours. The total counts were estimated manually after incubation period. This represents a viable count, that is, plate count $(\mathrm{CFU} / \mathrm{mL})=($ No of colonies on plate $) \mathrm{x}$ (dilution factor) (Obire and Anyanwu, 2009).

After cooling two drops of $1 \mathrm{~mL}$ sterilized flagyl (Metronidazole B.P.400 mg) were added to a proportion of mineral salt agar (MSA) to prevent the growth of fungi and two drops of $1 \mathrm{~mL}$ sterilized tetracycline were added to prevent the growth of bacteria. A loopful of the various colonies was added to $9 \mathrm{~mL}$ of distilled water and serial dilution was carried out, $0.1 \mathrm{~mL}$ of $10^{-3}$ and $10^{-4}$ of the dilutions were aseptically taken and placed on the sterile Petri dishes. For isolation of hydrocarbon utilizing bacteria, cooled MSA containing sterilized flagyl was poured on to the aliquot and rotated properly to mix well. Also, MSA containing sterilized tetracycline was used for the isolation of hydrocarbon utilizing fungi. The control sample was set up by adding $0.1 \mathrm{~mL}$ sterile distilled water into the Petri dishes in place of aliquot of dilute soil samples. Incubation was carried out at $30^{\circ} \mathrm{C}$ for 14 days (Atuanya and Ekanem, 2008). After 14 days, microbes that were able to grow on MSA were considered to be the hydrocarbon utilizing microorganisms in the soil sample. 


\section{CHARACTERIZATION OF HYDROCARBON UTILIZING BACTERIAL AND FUNGAL ISOLATES}

Pure stock cultures of crude oil utilizing bacterial and fungal isolates were examined for colonial appearance and used to carry out the following test: Gram staining, motility test, catalase test, citrate utilization test, indole test, hydrogen sulphide production test, methyl red-Voges Proskauer test, oxidase test and sugar fermentation test. Confirmatory identities of the bacteria were made using the Bergey's manual of determinative bacteriology and mycology.

\section{SCREEN TEST FOR CRUDE OIL UTILIZATION}

Bacteria and fungi that are able to grow on Mineral Salts Agar (MSA) containing hydrocarbons as energy and carbon source are considered to be the hydrocarbon-utilizing rhizomicrobes of Rhizophora racemosa. Pure cultures of these hydrocarbon-utilizing bacterial and fungal isolates were made by picking each of the colonies and streaking them on Mineral Salts Agar, Nutrient Agar and Potato Dextrose Agar separately. They were incubated at $28 \pm 2{ }^{\circ} \mathrm{C}$ for three days in the case of bacteria and five days in the case of fungi. Each of the isolates was later sub-cultured on MSA. Whatman size No1filter paper was soaked with sterile bonny light crude oil and was placed on the cultured MSA. The plates were incubated at $28 \pm 2^{\circ} \mathrm{C}$ for three days in the case of bacteria and seven days in the case of fungi. The plates were incubated upside down to prevent contamination. The slant stock cultures were made for both bacterial and fungal isolates (Atuanya and Ekanem, 2008).

\section{CRUDE OIL BIODEGRADATION USING SHAKE-FLASK TEST}

Organisms which are positive in the screening test were selected for shake flask degradation test. The biodegradation of the crude oil by these isolates were carried out using the same Mineral Salts Medium (MSM). One hundred and fifty millilitres of sterilized Mineral Salts broth were dispensed into 250mL conical flask, autoclaved and mixed with isolates which were inoculated by carefully picking a loopful of each isolate. One of the conical flasks was not inoculated which served as control. Five millilitres of $1 \% \mathrm{v} / \mathrm{v}$ crude oil was added to each flask and all the flasks were incubated at room temperature $\left(28 \pm 2^{\circ} \mathrm{C}\right)$ on a rotary shaker at $120 \mathrm{rpm}$ for 15 days (Atuanya and Omonigho, 2007).

\section{DETERMINATION OF TOTAL PETROLEUM HYDROCARBON (TPH) DEGRADATION}

Concentrations of total petroleum hydrocarbon were determined by taking $5 \mathrm{ml}$ each of the well shaken samples of the filtrate into cuvette (cell) and ran for absorbance using Total Organic Gas (TOG) and Total Petroleum Hydrocarbon (TPH) InfraCal Analyzer (HATR-T2 and CH) in order to determine the level of hydrocarbon and organic gas-nitrogen. Calculation of total petroleum hydrocarbon was as follows: $\underline{D F} X M F X$ ABS X Vol. of solvent

KEY: DF is Dilution Factor, MF is Multiplication Factor, and ABS is Absorbance 


\section{RESULTS}

\section{ISOLATION OF RHIZOMICROBES}

The following rhizomicrobes were isolated: ISO B1, ISO B2, ISO B3, ISO FI, ISO F2 and ISO F3

\section{TOTAL HYDROCARBON UTILIZING MICROBIAL COUNT}

Table 1 shows the total count for the hydrocarbon utilizing bacterial and fungal isolates; ISO B2 had the highest count among the bacterial isolates, followed by ISO B1 and ISO B3 had the least count. For fungal isolates ISO F3 had the highest count, followed by ISO F2 and ISO F1 had the least count.

Table 1: Total Hydrocarbon-Utilizing Bacterial Count and Total Fungal Count

\begin{tabular}{lllllll}
\hline Organisms & ISO B1 & ISO B2 & ISO B3 & ISO FI & ISO F2 & ISO F3 \\
\hline $\begin{array}{l}\text { Population } \\
(\mathbf{x ~ 1 0}\end{array}$ & 1.16 & 1.38 & 1.11 & 1.38 & 1.59 & 1.66 \\
cfu/mL) & & & & & & \\
\hline
\end{tabular}

\section{CULTURAL AND MICROSCOPIC CHARACTERISTICS OF HYDROCARBON UTILIZING FUNGAL}

\section{ISOLATES.}

Table 2 presents the cultural and microscopic characteristics of the fungal colonies isolated from rhizosphere of Rhizophora racemosa. The fungi include the following, Aspergillus niger, Aspergillus flavus and Candida albicans. These fungi were found to degrade crude oil.

Table 2: Cultural and Microscopic characteristics of fungal colonies from the rhizosphere of Rhizophora racemosa.

\begin{tabular}{|c|c|c|c|c|c|c|c|}
\hline Organism & Size & $\begin{array}{l}\text { Stripes } \\
\text { colour }\end{array}$ & Wall & Surface & Margin & Shape & $\begin{array}{l}\text { Conidia } \\
\text { surface }\end{array}$ \\
\hline Iso.F1 & $400-3000$ & $\begin{array}{l}\text { Slightly } \\
\text { brown }\end{array}$ & Smooth & Biserate & Entirely & Glubose & $\begin{array}{l}\text { Very rough } \\
\text { irregular }\end{array}$ \\
\hline Iso.F2 & $400-800$ & Palebrown & Roughened & VessicleBiserate & Metillacovery & $\begin{array}{l}\text { Glubose } \\
\text { ellipsoid }\end{array}$ & Smooth finely \\
\hline Iso.F3 & $\begin{array}{l}16 \mathrm{mb} \\
\text { (haphoid) }\end{array}$ & Cream & Thick & $\begin{array}{l}\text { Quieshy } \\
\text { spherical }\end{array}$ & $\begin{array}{l}\text { Short } \\
\text { inflated }\end{array}$ & $\begin{array}{l}\text { Septate } \\
\text { hyaline }\end{array}$ & $\begin{array}{l}\text { Roughened } \\
\text { Smooth }\end{array}$ \\
\hline
\end{tabular}

Iso.F1: Aspergillus niger, Iso. F2: Aspergillus flavus, Iso. F3: Candida albicans

Taxonomic characteristics of Hydrocarbon utilizing bacterial isolates from rhizosphere of Rhizophora racemosa.

Table 3 shows the taxonomic characteristics of bacterial isolates from rhizosphere of Rhizophora racemosa. The bacteria include the following, Marinococcus sp, Azotobacter sp and Acinetobacter sp. 
Table 3: Taxonomic characteristics of bacterial isolates from rhizosphere of Rhizophora racemosa.

\begin{tabular}{|c|c|c|c|}
\hline Cultural characteristics & Iso.B1 & Iso.B2 & Iso.B3 \\
\hline Cultural shape & Circular & Irregular & Rhizoid \\
\hline Colour & Cream & Cream & Milky \\
\hline Elevation & Flat & Raised & Raised \\
\hline Margin & Entire & Lobate & Pointed \\
\hline Wetness/dryness & Wet & Wet & Dry \\
\hline Transparency & Translucent & Opaque & Opaque \\
\hline $\begin{array}{l}\text { Morphological } \\
\text { characteristics }\end{array}$ & Iso.B1 & Iso.B2 & Iso.B3 \\
\hline Gram staining & + & - & - \\
\hline Cell morphology & Cocci & Cocci & Rod \\
\hline Arrangement & Cluster & Cluster & Single \\
\hline Biochemical tests & Iso.B1 & Iso.B2 & Iso.B3 \\
\hline Catalase & + & + & + \\
\hline Oxidase & + & - & - \\
\hline Indole & Nil & + & + \\
\hline Citrate & + & + & + \\
\hline Motility & - & + & + \\
\hline VP test & + & + & + \\
\hline Acid test & - & - & - \\
\hline Strict Anaerobic & Nil & + & $+/+$ \\
\hline Nitrate Reduction & Nil & Nil & \\
\hline Coagulase & - & - & \\
\hline Lactose & + & + & - \\
\hline Glucose & + & - & - \\
\hline Starch & + & + & + \\
\hline Mannitol & + & + & + \\
\hline Probable Isolate & Marinococcus sp & Azotobacter sp & Acinetobacter $\mathrm{sp}$ \\
\hline
\end{tabular}

- is negative and + is positive

\section{SCREEN TEST FOR CRUDE OIL UTILIZATION}

The result of the screen test for the utilization of crude oil (hydrocarbon) as the sole carbon source by the rhizomicrobes is presented in Figure 1; it showed that Acinetobacter sp, Azotobacter sp and Marinococcus sp produce turbidity in the broth culture after seven (7) days and the turbidity increased over the period of twenty-eight days. Among the rhizobacteria Micrococcus sp. showed the highest turbidity followed by Acinetobacter sp.

and Azotobacter sp., showed the lowest turbidity after the 28 days. Among the fungi, Aspergillus flavus showed the highest turbidity after 28 days, followed by Candida albicans and Aspergillus niger showed the least turbidity. Among the hydrocarbon-degrading rhizomicrobes. Aspergillus flavus was found to have the highest turbidity and Azotobacter had the lowest turbidity. 


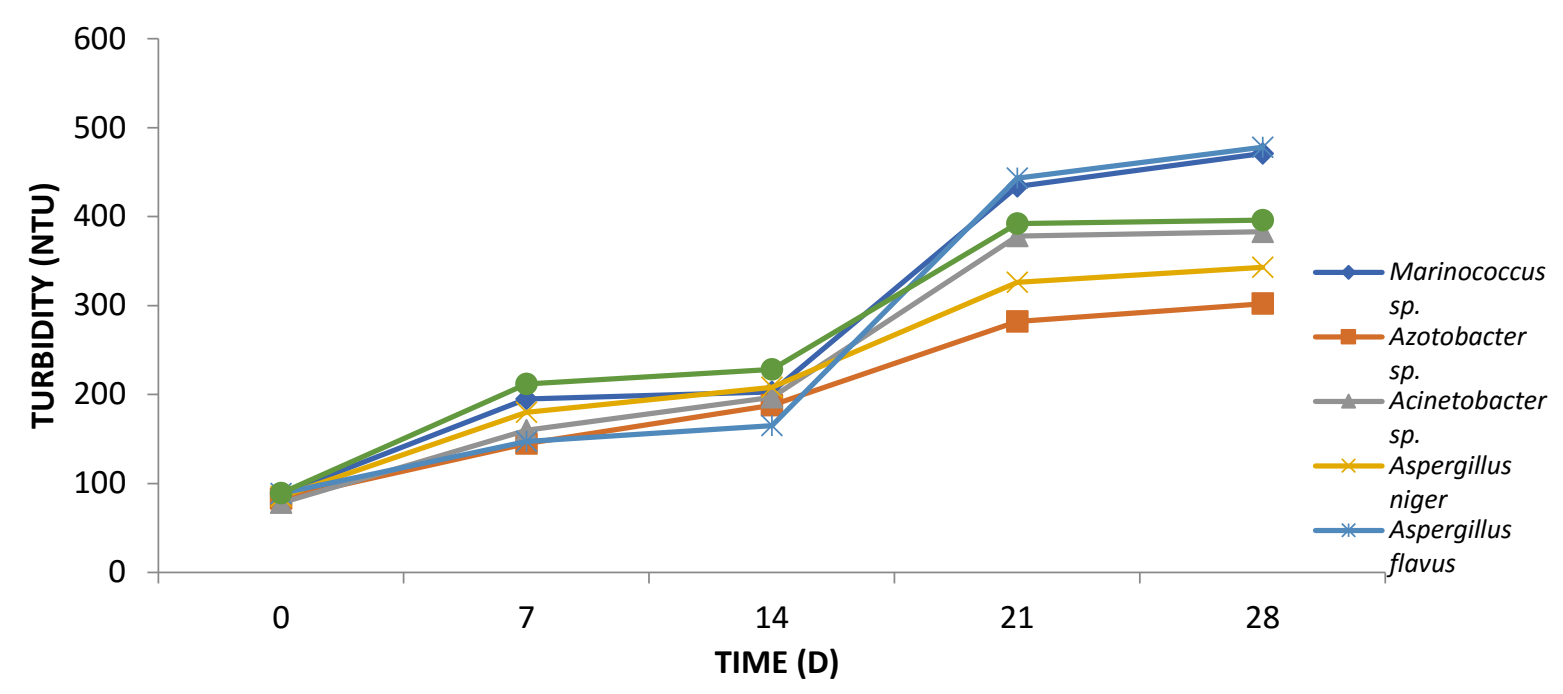

Figure 1: Turbidity of the rhizomicrobes during biodegradation of crude oil.

\subsection{TOTAL ORGANIC GAS (NITROGEN) CONTENREDUCTION IN CRUDE OIL CONTAMINATED SOIL BY THE ISOLATES.}

Results in Figure 2 shows that the rate and level of nitrogen reduction in Azotobacter sp. was the highest from (0.92 to 0.06$) \mathrm{mg} / \mathrm{L}$, followed by Acinetobacter sp. (0.90 to 0.07$) \mathrm{mg} / \mathrm{L}$ while Marinococcus sp. (0.92 to 0.08$) \mathrm{mg} / \mathrm{L}$ demonstrated the least reduction. Also, for fungi, Candida albicans (0.90 to 0.078$) \mathrm{mg} / \mathrm{L}$ had the highest nitrogen reduction followed by Aspergillus niger (0.92 to 0.08$) \mathrm{mg} / \mathrm{L}$ and Aspergillus flavus (0.90 to 0.08) $\mathrm{mg} / \mathrm{L}$.

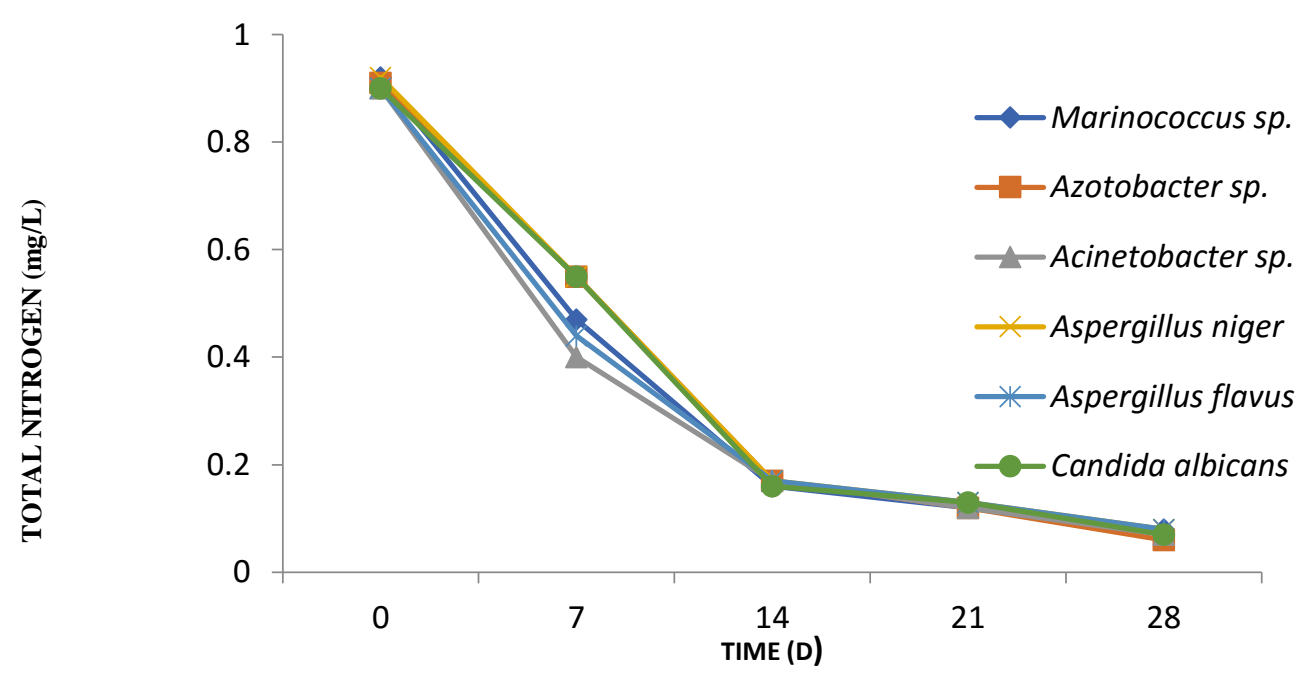

Figure 2: Total Nitrogen Reduction in Soils Contaminated with Crude Oil by The Rhizomicrobes

\section{TOTAL PETROLEUM HYDROCARBON (TPH) REDUCTION IN CRUDE OIL CONTAMINATED SOIL} BY THE ISOLATES

Figure 3 shows that the level of total petroleum hydrocarbon (TPH) decreased gradually during the 28 days. Results showed that the rate and level of TPH reduction was more in Acinetobacter sp. than in others from $(150$ to $<0.0031)$ mg/L, followed by Azotobacter sp. (149 to 43.49) mg/L while Marinococcus sp. (150 to 61.69) mg/L had the least reduction. Figure 3.3 also showed that for fungi, Candida albicans (148 to 2.68$) \mathrm{mg} / \mathrm{L}$ had the highest reduction followed by Aspergillus niger (150 to 4.21) $\mathrm{mg} / \mathrm{L}$ and Aspergillus flavus demonstrated the least reduction. 


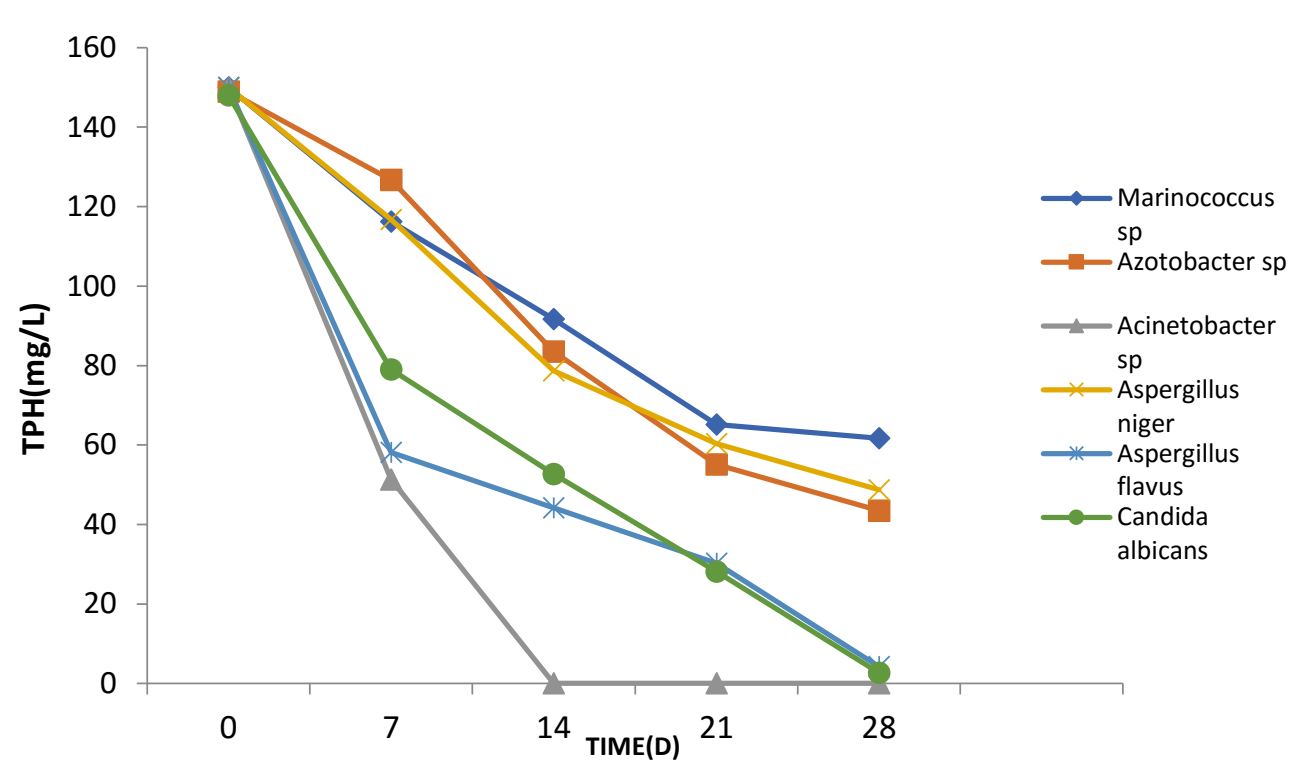

Figure 3: Total Petroleum Hydrocarbon (TPH) reduction in soil contaminated with crude oil by the isolates.

\section{HYDROCARBON -UTILIZING MICROBIAL COUNTS DURING BIODEGRADATION OF CRUDE OIL}

Figure 4 showed that HUM count increased gradually from day (7) and throughout the 28 days except for Acinetobacter sp. and Candida albicans which exhibited reduction after 21 days.

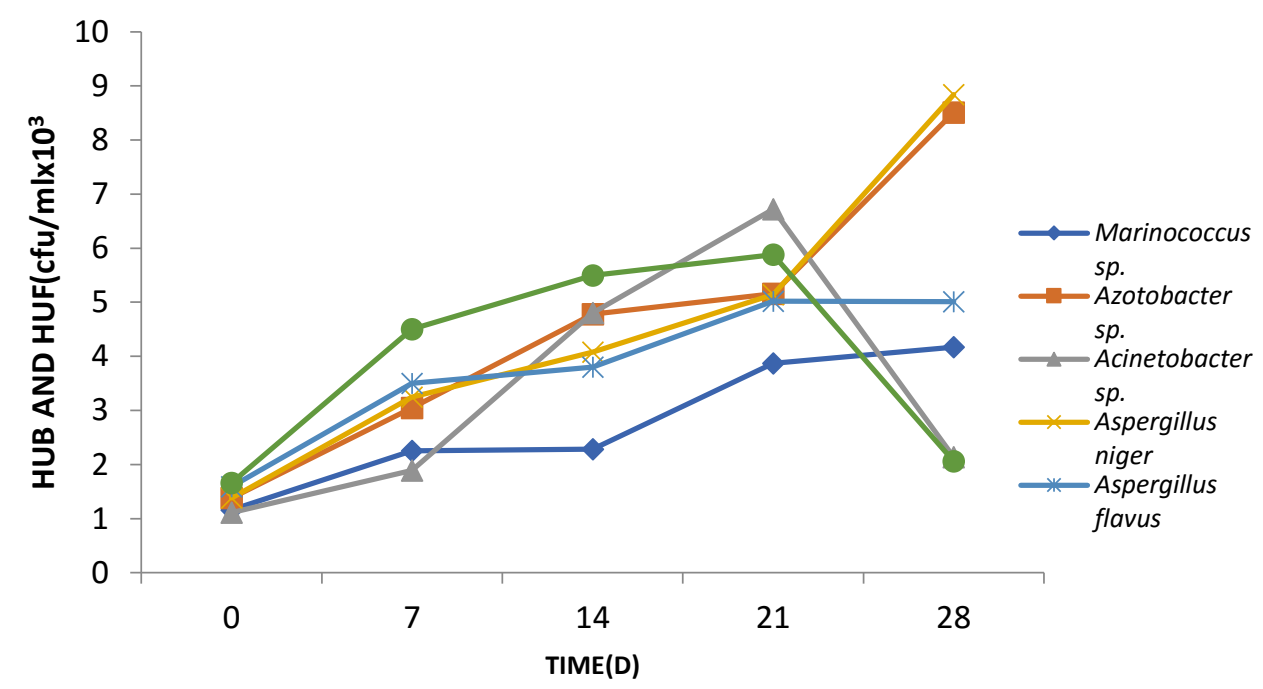

Figure 4: Total Microbial Count during biodegradation of crude oil. 


\section{DISCUSSION}

Findings from this work on the biodegradation potential of the rhizospheric microorganisms of $R$. racemosa in crude oil contaminated mangrove swamp in the Niger Delta demonstrated that there were presence of fungi (mycorrhiza) and bacteria (rhizobacteria) in the rhizosphere of $R$. racemosa. This result supports a previous report that diverse groups of bacteria and fungi occur in the rhizosphere of plants (Compant et al., 2010; Kumar et al.,2012).The microorganisms found in the rhizosphere of Rhizophora racemosa have the capacity to degrade hydrocarbon in polluted soil. These finding agreed with the report of Atlas and Hazen (2011) that when there is hydrocarbon in an environment, there must be in existence hydrocarbon utilizing microorganisms.

In this research the bacteria and fungi found to be associated with effective degradation of hydrocarbon are Marinococcus sp., Azotobacter sp., Acinetobacter sp., Aspergillus niger, Aspergillus flavus and Candida albicans. This agreed with the report of Sarkar et al. (2018) that several bacteria such as Acinetobacter sp. have been found to play vital roles in petroleum hydrocarbon degradation. Also Compant reported that hydrocarbons can be degraded by some microorganisms examples of such include fungi belonging to the genera Aspergillus and yeasts which include Candida (Compant et al., 2010).

The results in Figure 1 show that all the rhizomicroorganisms considerably utilized crude oil as the sole carbon source. The turbidity increased gradually from day (7) and throughout the 28 days of experiment for most of the isolates except for Acinetobacter sp and Candida albicans which started to retrogress after 21 days. This confirmed a previous report that the microbial load increases considerably over time (Atuanya et al., 2013). Acinetobacter sp and Candida albicans were the only organisms that demonstrated three major phases of microbial population these are growth phase, the stationary phase and the decline phase.

The results in Figure 2 show that the level of total nitrogen (TN) reduced gradually during the 28 days. This indicates that these rhizomicrobes both bacteria and fungi found in the rhizosphere of Rhizophora racemosa effectively utilized nitrogen for growth. The results confirmed the fact that Azotobacter sp. and Acinetobacter sp. were involved in nitrogen fixation. The results indicated that Azotobacter sp. had the highest potentials for utilisation nitrogen in contaminated mangrove swamp soil. Also, for fungi, Candida albicans (0.90 to 0.078) mg/L had the highest potentials for utilization of nitrogen in crude oil contaminated mangrove swamp soil. This was followed by Aspergillus niger (0.92 to 0.08) $\mathrm{mg} / \mathrm{L}$ and Aspergillus flavus (0.90 to 0.08) $\mathrm{mg} / \mathrm{L}$.

The results in Figure 3 indicate that the level of TPH reduced gradually during the 28 days. This indicates that the hydrocarbon utilizing rhizomicrobes found in the rhizosphere of the Rhizophora racemosa effectively utilized the crude oil for growth. According to the results Acinetobacter sp. $(150$ to $<0.0031) \mathrm{mg} / \mathrm{L}$ had the highest potentials for utilisation and degradation of crude oil in contaminated mangrove swamp soil, followed by Azotobacter sp. (149 to 43.49) mg/L while Marinococcus sp. (150 to 61.69) mg/L demonstrated the least potentials. This agreed with the report of Kumar et. al. (2015) that formulated root endophytic fungus and plant growth promoting rhizobateria enhances the biodegradation process. Also, for fungi, Candida albicans (148 to 2.68) $\mathrm{mg} / \mathrm{L}$ had the highest potentials for utilization and degradation of hydrocarbon in crude oil contaminated mangrove swamp soil, this agreed with a former report that mycorrhizal associations possess some unique characteristics which enable them to enhance the degradation of organic pollutants (Meharg and Cairney, 2000; McNear 2013). Aspergillus niger 
(150 to 4.21$) \mathrm{mg} / \mathrm{L}$ had the second highest potentials for hydrocarbon utilization and degradation and Aspergillus flavus (150 to 48.74$) \mathrm{mg} / \mathrm{L}$ demonstrated the least potential for utilization and degradation of crude oil.

The results in Figure 4 showed that total hydrocarbon - utilizing microbial count increased gradually throughout the 28 days of the research for most of the isolates except for Acinetobacter sp. and Candida albicans which started to retrogress after 21 days. This confirmed a previous report that the microbial load increases considerably over time (Atuanya et al., 2013). For all the rhizomicrobes Aspergillus niger showed the highest increase, followed by Aspergillus flavus and Candida albicans, this also confirmed Lynch's report that fungi are the most abundant in the rhizosphere (Lynch, 1990).

\section{CONCLUSION}

In conclusion, the investigations showed that the rhizosphere of Rhizophora racemosa contains some indigenous microorganisms, both bacteria and fungi, which are capable of effectively degrading hydrocarbons in crude oilcontaminated mangrove swamp soil in the Niger Delta etc. Hydrocarbon removal efficiencies of these rhizomicrobes in a hydrocarbon impacted mangrove ecosystem can reach 100\% using Acinetobacter sp and up to $98 \%$ using Candida albicans over a period of 28 days.

\section{REFERENCES}

Adegbehin, J. O. (1993). Mangroves in Nigeria. Conservation and sustainable utilization of mangrove forests in Latin America and Africa regions part II-Africa. International Society for Mangrove Ecosystems and Coastal Marine Project of UNESCO. Mangrove Ecosystems Technical Reports. In E.D. Diop, volume 3 edition. (Page 1-3).

Amanchukwu, S.C., Obafemi, T.A. and Okpokwasili, G.C. (1989). Hydrocarbon degradation and Utilization by palm wine yeast isolates: FEMS Microbiology Letters. 57:151-154.

Atlas, R.M. and Hazen, T.C. (2011).Oil Biodegradation and Bioremediation: A Tale of the Two Worst Spills in U.S.History.Environment Science and Technology. 45 (16):6709-6715.

Atuanya, E.I., Bolanle O.R. and Ajuzie, C.U. (2013).Phytoremediation of crude oil contaminated mangrove soil by Rhizophora racemosa. Nigerian Journal of Science and Environment.12 (2): 1-10.

Atuanya, E.I. and Ekanem, N.O. (2008). Degradative potentials of indigenous bacteria from rubber processing factory effluent. Journal of Research in Bioscience. 4 (3): 56-60.

Atuanya, I.E. and Omonigho I.E. (2007).Fungi applicable to biodegradation of brewery effluent. Journal of Biological Science Research. 2(1):18-22.

Brime-Combe, M.J., Deleij, F.M. and Lynch, J.M. (2007). Rhizodepositions and Microbial populations. In Pintor, R., Varanin, Z. and Nannipierl, P. (eds). The Rhizosphere Biochemistry and Organic Substances at the Soil Plant Interface, CRC Press, Taylor and Francis Group. Boca Rator. London, New York 73-103pp. 
Compant, S., Clement, C. and Sessitsch, A. (2010). Plant growth-promoting bacteria in the rhizo and endosphere of plants: their role, colonization, mechanisms involved and prospects for utilization. Soil Biology and Biochemistry.42:669-678.

Eleanya, K., Agbeja, B.O., Ijeomah, H.M. (2015). Socio-Economic Importance of Mangrove Forests in Akassa Island of Niger Delta, Nigeria. Production Agriculture and Technology Journal. 11 (1): $1-11$

Flowers, T. J. and Colmer, T. D. (2015). Plant salt tolerance: adaptations in halophytes. Annals of Botany. 115 (3): $327-331$

Giri, C., Ochieng, E., Tieszen, L.L., Zhu, Z., Singh, A., Loveland, T., Masek, J. and Duke, N. (2010). Status and distribution of mangrove forests of the world using earth observation satellite data. Global Ecology and Biogeography. 20 (1): 154-159.

Johanson, J.F., Paul, L.R., Finlay, R.D. (2004).Microbial interactions in the mycorrhizosphere and their significance for sustainable agriculture. FEMS Microbiology Ecology. 48:1-13.

John, R.C., Akpan, M.M., Essien, J.P. and Ikpe, D.I. (2010).Impact of crude oil pollution on the densities of nitrifying and denitrifying bacteria in the rhizosphere of tropical legumes grown on wetland soil. Nigeria Journal of Microbiology. 24 (1) 2088-2094.

Kuiper, I., Lagendijk, E.L., Bloeemberg, G.V.and Lugtenberg, B.J. (2004).

Rhizoremediation: A beneficial plant-microbe interaction. Molecular Plant Microbe Interact.17 (1) 615.

Kumar V., Sarma, M.V., Saharan, K., Srivastava R., Kumar L. and Sahai, V. (2012).Effect of formulated root endophytic fungus Piriformospora indica and plant growth promoting rhizobateria fluorescent pseudomonads R62 and R81 on Vigna mungo. World Journal of Microbiology and Biotechnology. 28:595603.

Lynch J. I. (1990). Introduction: Some consequences of microbial rhizosphere competence for plant and soil: In Lynch, JM eds. The rhizosphere. John Wiley and sons Chichester, UK. Page 100.I

McNear Jr., D.H. (2013).The Rhizosphere: Roots, Soil and Everything in Between. Nature Education Knowledge. $1: 3-4$ 
Meharg, A.A. and Cairney, J.W.G. (2000). Ectomycorrhizas-extending the capabilities of rhizosphere remediation. Soil Biology and Biochemistry.32:1475-1484.

Morgan,F., Poinsot,V.,Andre,O., Puech-Pages,V., Haouy, A., Gueunier,M., Cromer,L., Giraudet, D., Formey,D., Niebel,A., Andres- Martinez,E., Driguez, H.,Cecard,G. and Denarie,J.(2011). Fungal Lipochitooligosaccharide Symbiotic Signals in Arbuscular Mycorrhizal.Nature.469:58-64.

Nnubia, C. and Okpokwasili, G.C. (1992). The microbiology of drill mud cutting from a new offshore oil field in Nigeria: Environmental Pollution. 82:153-156.

Obire, O. and Anyanwu, E.C., (2009). Impact of various concentrations of crude oil on fungal populations of soil. International Journal of Environmental Science and. Technology. 6:211-218.

Sakar, J., Roy, A., Dutta, A., Pal, S., Sakar, P.,Gupta, A.(2018).Biostimulation and bio augmentation of native microbial community accelerated bioremediation refinery sludge. Bioresource

Technology 253:22-32 